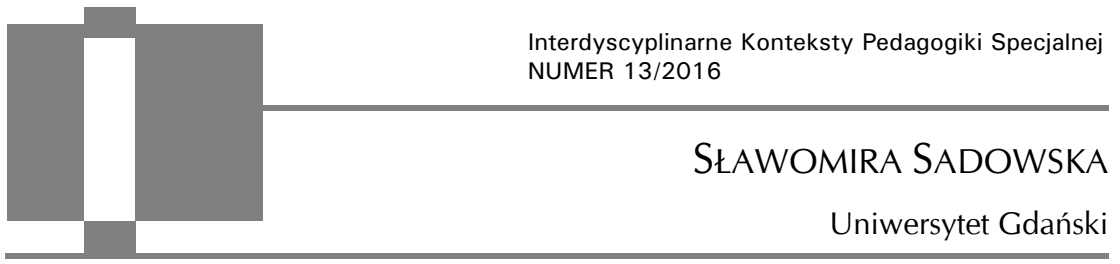

\title{
Studia na kierunku pedagogika specjalna jako przestrzeń czytania naukowego
}

\begin{abstract}
Sławomira Sadowska, Studia na kierunku pedagogika specjalna jako przestrzeń czytania naukowego [Studies in the field of special pedagogy as a scientific reading space]. Interdyscyplinarne Konteksty Pedagogiki Specjalnej, nr 13, Poznań 2016. Pp. 9-27. Adam Mickiewicz University Press. ISSN 2300-391X
\end{abstract}

The author describes the properties of modern ways of "reading in science". It emphasizes the relationship between the type of text (digital, printed) and the kind of reading activity. He points out that reading science texts by scholars is rarely done in full and in linear order. Reading in science, requires active engagement in text, information processing and efficient selection to fully understand content. Analyzing the changes that have taken place with the advent of the $C$ generation, he analyzes "reading in college". He argues that contemporary students (special education) - representatives of the computerized generation - connected -always clicking - have dropped printed text and are not interested in books as a source of knowledge. Although they have a proficiency in searching online resources, they experience difficulties in using the text and its content. By copying the thesis, the author presents the results of the research conducted in this field and refers to many publications on this subject. Clearly recognizes the need to prepare future students for a rational and critical use of scholarly reading, to learn how to study a scholarly work (both at the earlier stages of education and within the university education system). Also, believes that pedagogical thinking and action derive both from the association with the scientific texts and from reading literature. Reading is an irreplaceable way to enrich the sensitivity and imagination of future teachers (special).

KEY WORDS: reading text / reading, student's reading (special education), reading value, reading in science, reading in college, reading crisis, learning culture, generation C 


\section{Wprowadzenie}

Dlaczego po wielu latach pracy jako nauczyciel akademicki myślenie moje kieruję w stronę czytania w obszarze studiów? Wstępnie mogłabym powiedzieć, podobnie jak redaktorki książki Szwecja czyta. Polska czyta1, że u źródeł były emocje - lęk, że czytelnictwo coraz częściej jest elitarnym hobby i obawa, że tego trendu nie da się odwrócić. Zaniepokojenie to wyrasta z przekonania, że pedagogiczne myślenie i działanie czerpie $\mathrm{z}$ obcowania $\mathrm{z}$ tekstami naukowymi, ale i z czytania literatury. To czytanie literatury budzi naszą refleksję $\mathrm{w}$ polu wartościowego życia, jest pomocne $\mathrm{w}$ poszukiwaniu własnej drogi myślowej, buduje naszą kompetencję do przewartościowywania własnych postaw w świecie. Lech Witkowski - filozof edukacji, pedagog - prowadząc rozważania w odwołaniu do przestrzeni tekstów kultury, przekonuje, że od autorów nie musimy oczekiwać wiążących i zamykających kwestię odpowiedzi, ale impulsów dla własnego myślenia. $\mathrm{W}$ tym duchu w książce Wyzwania autorytetu rozważa problem autorytetu symbolicznego, stwierdzając, że "autorytetem staje się ta osoba, której spotkanie (choćby w warstwie historycznie dostępnego przekazu) było ważne dla naszego rozwoju, którą uznajemy za katalizator naszych przemian wewnętrznych, wobec której mamy dług wdzięczności, choć bez poczucia pełnej uległości" 2 . O nastawieniu do czytania napisał:

Czytając muszę się czymś wzbogacić, jeśli tekst ma mieć dla mnie znaczenie, jeśli ma przemówić - choć mogę być do tego całkowicie albo częściowo nieprzygotowany, niezdolny. W wysiłku zdobywania się na dialog próbuję się do niego zbliżyć. Chcę mieć szansę, by dał mi do myślenia, bez względu na to, czy we wszystkim go rozumiem, a tym bardziej czy się we wszystkim zgodzę. Zdarzenie lektury ma być efek-

${ }^{1}$ Szwecja czyta. Polska czyta, red. K. Tybylewicz, A. Diduszko-Zyglewska, Wydawnictwo Krytyki Politycznej, Warszawa 2015.

${ }^{2}$ L. Witkowski, Wyzwania autorytetu, Oficyna Wydawnicza „Impuls”, Kraków 2009, s. 17. 
tem zderzenia, wstrząsu, przebudzenia. (...) Opowiadać się warto za lekturą życiodajną, w trosce o wzbogacenie własnego instrumentarium i własnej wrażliwości i wyobraźni³.

Czy życiodajne chwile związane z czytaniem tekstów odnieść można do obcowania studenta $\mathrm{z}$ przestrzenią publikacyjną myśli naukowej z obszaru podjętych studiów? W perspektywie naszych życzeń z pewnością wyrazimy odpowiedź twierdzącą. Nie chodzi bowiem o to, by tekst traktowany był przez studentów jedynie jako źródło informacji, odtworzenia definicji, pojęć, tez, toków rozumowań. Wartości czytania w procesie studiowania nie wiążemy jedynie $\mathrm{z}$ ",analitycznie wąską" postawą czytelniczą. Uznajemy, że z poglądami autorów książki trzeba się zmierzać, przyglądać się im, zgadzać się z nimi lub nie. O absolwentach studiów chcemy myśleć nie tylko jako o posiadaczach dyplomu, ale o ludziach, którzy zyskali zachętę i gotowość nieulegania iluzji nieomylności autorów książek oraz kompetencję do rozumienia złożoności świata i dialogicznego w nim bycia.

Nie kryjąc własnego zaangażowania w urzeczywistnianie tych postaw czytelniczych u studentów pedagogiki specjalnej, stwierdzę, że doświadczam często „porażek dydaktycznych”. Próba zmierzenia się z ich zrozumieniem doprowadziła do powstania niniejszego tekstu. Była to droga odtworzenia możliwie pełnego profilu zakorzenienia tych porażek we współczesnym świecie, w kształcie studiów, w zmonopolizowaniu przestrzeni tekstów do czytania przez prowadzących zajęcia. W prowadzonych analizach poruszam się więc pomiędzy polem czynności czytania tekstów naukowych przez uczonych i realizowaniem tej czynności przez studentów, pomiędzy charakterystyczną przestrzenią cech i sposobów realizacji czytania tekstów naukowych w erze tekstów drukowanym a przestrzenią cech i sposobów realizacji czytania tekstów naukowych w erze mediów elektronicznych. Ważnym kontekstem odniesień

${ }^{3}$ L. Witkowski, Wstęp do fenomenologii czytania (uwagi nie tylko seminaryjne), [w:] Między pedagogika, filozofią i kulturą: studia, eseje, szkice. T. 3., red. L. Witkowski, Instytut Badań Edukacyjnych, Warszawa 2007, s. 44. 
dla czytania naukowego $\mathrm{w}$ przestrzeni studiów jest szerokie pole czytelnictwa w Polsce i zmiany w edukacji wyższej, w tym w edukacji nauczycieli i pedagogów.

\section{Czytanie w nauce}

Wobec ogólnego spadku czytelnictwa w Polsce (o czym donoszą kolejne raporty Biblioteki Narodowej) warto zauważyć, że badania pokazują, iż uczeni czytają więcej, szybciej, w większym zakresie. Liczba artykułów czytanych rocznie się podwoiła, a czas na czytanie artykułu spadł o $25 \%$. Związane jest to z faktem, że w coraz większym stopniu czytelnictwo odbywa się w środowisku cyfrowym.

Marek Nahodko, prowadząc analizę czynności czytania tekstów naukowych $\mathrm{w}$ okresie transformacji, dokonuje porównania sposobów realizacji tego procesu $\mathrm{w}$ zależności od tego, czy dotyczy tekstów drukowanych na papierze, czy publikowanych $\mathrm{w}$ formie elektronicznej4. Wskazuje, że czytanie tekstów naukowych przez uczonych rzadko odbywa się $\mathrm{w}$ całości $\mathrm{i} \mathrm{w}$ porządku liniowym. Czytanie naukowe jest czytaniem nieciągłym w przestrzeni - to czytanie bez linearnego sekwencyjnego porządku, czytanie urywków, przeglądanie różnych tekstów. Dla czytania książek drukowanych charakterystyczne jest przeglądanie (rozpoczynane od spisu treści, indeksu), potem "skanowanie” (przemieszczanie nieliniowe) małych części, potem uważne czytanie wybranych fragmentów, rzadko całości. Nieliniowe przemierzanie tekstu odnosi się także do czytania drukowanych artykułów: rozpoczynanie od abstraktu (niektórzy go pomijają), kilka akapitów ze wstępu, jeśli jest interesujący, przechodzi się do wniosków, potem czyta całość, przeskakując w przód i w tył.

${ }^{4}$ M. Nahodko, Wptyw nowych technologii na czytanie naukowe, [w:] Czytelnictwo w dobie informacji cyfrowej. Rozwój, bariery, technologie, red. M. Wojciechowska, Wydawnictwo SBP, Warszawa 2015. 
Działanie użytkowników pracujących $\mathrm{w}$ tzw. naukowych środowiskach wyszukiwawczych (Scopus, Google Scholar, WoS, MSN Academic itp.) również wskazuje na nieciągłe sposoby czytania naukowego. Allen Renear określa je jako czytanie „śledcze”, wskazując, że są to działania podświadome, kinestetyczne, przypominające grę wideo.

W pospiechu, jakby podświadomie [czytelnicy - S.S.] wykonują zaskakujące działania: tworzą zapytania, jakby chcieli odnaleźć znane sobie dokumenty lub powtórzyć wyniki wyszukiwania rzeczowego; podążają za cytowaniami wstecz i w przód; wykonują pospieszną ocenę relewancji, dokonują ewaluacji wpływu (impact), jakości; unikają płatnych stron wydawców, agregatorów, a poszukują egzemplarzy dostępnych w Oopen Access; lokalizują i porównują słowa kluczowe, definicje, protokoły, wyniki wyszukiwania 5 .

Sesje opisywane są przez użytkowników naukowych środowisk wyszukiwawczych jako pożyteczne, nawet jeśli w efekcie żaden artykuł nie został przeczytany.

Biorąc pod uwagę opisane wyżej zachowania naukowców, można odnieść wrażenie, że ich celem podczas wyszukiwania i nawigacji $\mathrm{w}$ środowisku wyszukiwawczym nie jest wyszukiwanie tekstu do czytania, ale raczej znalezienie sposobu na uniknięcie potrzeby czytania. Jeśli weźmiemy pod uwagę narzędzia stosowane od dawna przez naukowców, nie jest to niczym nowym ${ }^{6}$. Relewancję artykułów bez ich czytania pozwalają określić indeksowanie, cytowania. Poziom artykułów bez ich czytania pozwalają określić abstrakty, przeglądy literatury. Zawarte $\mathrm{w}$ czytanych artykułach stany badań pozwalają na orientację $w$ innych artykułach bez ich czytania. Formatowanie tekstu (wykazy, terminologia) i aparat pomocniczy (spisy treści, odsyłacze, rysunki) pozwalają na wykorzystywanie artykułów bez ich czytania. Pomagają nam w tym także koledzy uczeni i studenci. Jest to działanie polegające na szukaniu

\footnotetext{
${ }^{5}$ Za: ibidem, s. 144.

${ }^{6}$ Por. Ibidem, s. 144-145.
} 
właściwej postawy wobec ogromnej liczby książek, która w innym przypadku mogłaby nas przytłoczyć. Taka postawa nie-czytania jest różna od nieczytania.

Dodać można, że uczeni często są wolni od pokusy korzystania z komputera. Często czytają w domu, w sposób nieciągły przeskakują do przodu i wstecz tekstu. Jednak uważna lektura kanoniczna, gdy czytelnik przemierza tekst liniowo, także jest obecna w czytaniu naukowym. Czysto trwałe czytanie całych książek występuje jako czytanie uzupełniające w obszarze tematów przyległych do głównego nurtu zainteresowań. Edward Hajduk - filozof, pedagog, socjolog - w rozmowie z Elżbietą Kołodziejską, na pytanie, czego szuka w książkach, odpowiedział:

Myślę, że częściej jednak poglądów odbiegających od moich. Nie wiem, czy to jest wyćwiczone, trudno mi bowiem mówić, że mam taki program, żeby poznawać poglądy, z którymi niezupełnie bym się chciał zgodzić. Oczywiście niekiedy jest to wybór niezupełnie przemyślany, na przykład Niebezpieczne idee we wspótczesnej nauce, którą to książkę zobaczyłem w księgarni. [...] Jest tam wiele poglądów, których sam bym nie głosił, właściwie nawet ich nie akceptuję, ale to nie ma znaczenia. Ja wiem, że są takie poglądy ludzi nauki, także upowszechniane przez ludzi nauki. Pożytek $z$ tej lektury jest bardzo duży, ponieważ dostrzegam, że w nauce, szczególnie w naukach społecznych, są dalece rozbieżne spojrzenia na ten sam problem ${ }^{7}$.

Czytaniu naukowców towarzyszy robienie notatek. Stanowi ono pomoc w lokalizacji ważnych elementów lub cytowań do wykorzystania we własnych artykułach lub książkach. W odwołaniu do słów profesora Hajduka można powiedzieć, że wielu ludzi nauki to czytelnicy - barbarzyńcy. O sobie powiedział:

ja muszę podkreślić jakieś zdanie, znak zapytania czy uwagę postawić [...] Chwytam się na tym, że jak książka jest moja, to nie mam oporów, żeby się tak zachowywać. Nawet to ma też techniczne walory - mogę

7 E. Kołodziejska, Przy herbacie. Rozmowy z Edwardem Hajdukiem, Wydawnictwo Uniwersytetu Zielonogórskiego, Zielona Góra 2012, s. 122. 
wrócić i patrzeć, co podkreślałem. Jak podkreślam, to znaczy uznałem to za znaczące dla mnie albo nowe, dyskusyjne. I tak się zachowuję ${ }^{8}$.

Podkreślić należy, że cechą czytania naukowego w sensie czasowym jest czytanie trwałe - nieprzerywane innymi czynnościami. Czytanie naukowe jest więc długotrwałe w czasie i łączy oba sposoby czytania w przestrzeni - czytanie w porządku linearnym i sekwencyjnym oraz bez takiego porządku. W czytaniu naukowym występują wszystkie rodzaje czytania (zgodnie z podziałem Catherine Marshal): czytanie liniowe, przeglądanie (przemierzanie tekstu jest nadal liniowe, lecz zrozumienie jest poświęcane dla szybkości; celem jest uchwycenie istoty tekstu); skanowanie (przemierzanie staje się nieliniowe; czytelnik przeskakuje do przodu i do tyłu tekstu; celem jest często ocena lub decyzja o dalszych czynnościach), szukanie (czytelnik skanuje szybko tekst w poszukiwaniu określonego elementu strony, np. słów, bez celu zrozumienia); powtórne czytanie - meta-czytanie ${ }^{9}$.

Ważne dla opisu czytania jest też kryterium zaangażowania w tekst - wyróżnia się aktywności od czytania aktywnego do pasywnego. Cechą czytania środowisk naukowych jest czytanie aktywne. Łączy się ono z myśleniem krytycznym, podejmowaniem decyzji. Dotyczyć może pracy z jednym i z wieloma tekstami. Dla zauważenia powiazań i wyciągania wniosków naukowcy pracują często na kilku tekstach jednocześnie. Czytając online, często teksty drukują do czytania. Drukowane urywki sortowane są według przydatności. Część z tych papierów jest "gorąca" układana w bezpośrednim zasięgu. Inne są „ciepłe” - przeznaczone do późniejszego wykorzystania lub potencjalnego wykorzystania. Na pewnym etapie dokumenty stają się "zimne" i są usuwane $\mathrm{z}$ biurka.

Przedstawiciele świata nauki, niezależnie od prezentowanej dyscypliny, odnosząc się do codzienności pracy naukowej, wskazują na czytanie. Przykładów na takie spojrzenie nie brakuje w książce

\footnotetext{
8 Ibidem, s. 120.

9 Por. M. Nahodko, op. cit., s. 141-142.
} 
Uniwersytet Jagielloński: Z naukowcami o nauce ${ }^{10}$. Dodać należy, że dla wielu przedstawicieli nauki własny księgozbiór jest czymś, co szczególnie pielęgnują. Doskonale pamiętam wizyty w domach moich Profesorów, które przepełnione były książkami z pedagogiki specjalnej, z dyscyplin ościennych, a często także z dość odległych obszarów nauki. Książki te miały różne "historie”. Zacytuję w tym kontekście słowa Jacka Dehnela z książki Młodszy księgowy. O książkach, czytaniu i pisaniu.

Widać po nich, z jakiego domu pochodzą, jak się z nimi obchodzono, gdzie trzymano - jedne mają pozaginane rogi i zaplamione strony, inne czuć papierosowym dymem, jeszcze inne należały do pedantów, którzy rozginali książkę tylko na czterdzieści pięć stopni, tyle, żeby było widać druk, ale żeby nie zdefasonować grzbietu; zachowywali obwoluty w nienagannym stanie i wklejali bardzo eleganckie ekslibrisy ${ }^{11}$.

\section{Czytanie na studiach}

Nieodłącznym elementem uniwersyteckiego charakteru studiów jest studiowanie - w znaczeniu nie tyle uczenia się na wyższej uczelni, co gruntownego poznawania, co wiążę się z pogłębionym czytaniem. Codzienne doświadczenie i badania jednoznacznie pokazują, że dla studentów internet to często podstawowe źródło informacji. Z badań Mariusza Jędrzejki wynika, że 54\% studentów uczelni publicznych i 72\% niepublicznych deklaruje, że podczas pisania pracy dyplomowej (zarówno licencjackiej, jak i magisterskiej) Wikipedia służyła im jako główne źródło informacji ${ }^{12}$. Jak w przestrzeni studiów czytają studenci kierunków pedagogicznych?

10 Uniwersytet Jagielloński: Z naukowcami o nauce, red. P. Żabicki, Kraków 2016, www.nauka.uj.edu.pl [dostep: 29.08.2016].

11 J. Dehnel, Młodszy księgowy. O książkach, czytaniu i pisaniu, Wydawnictwo: W.A.B., Warszawa 2013, s. 363.

${ }_{12}$ N. Bednarska, Wikipedia na uczelni $i$ w szkole - przyszli nauczyciele o Wikipedii, „Ruch Pedagogiczny” 2015, nr 1, s. 147. 
Katarzyna Borawska-Kalbarczyk ${ }^{13}$ przeprowadziła badania sondażowe z wykorzystaniem ankiety wśród 226 studentów pierwszego roku kierunku pedagogika. Pytania zorientowane były na wybrane aspekty związane ze studiowaniem (typu: źródła informacji, uczenie się z książek vs korzystanie z treści dostępnych w sieci, wielozadaniowość, liczba czytanych książek czy korzystanie z czytelni). Niepokojąca jest otwartość postawy 10\% studentów przyznających się do nieczytania. 16\% studentów twierdzi, że szukanie informacji w sieci jest jedyną opcją znajdywania informacji - gdy zawiodą zasoby cyfrowe, nie podejmują dalszych czynności poszukiwawczych. Co trzeci student uważa, że korzystanie wyłącznie z materiałów z sieci wystarczy do zaliczenia przedmiotu. Przygotowanie się do ćwiczeń w wielu przypadkach polega na wydrukowaniu gotowych materiałów (informacji podanych w punktach) na powszechnie znanych, polecanych sobie stronach internetowych. Blisko połowa jawnie przyznaje się, że wykorzystuje pracę intelektualną innych, kserując od nich notatki. Negatywny obraz buduje także postawa traktowania przez studenta biblioteki i czytelni jako ostateczności. Teksty naukowe - jeżeli w ogóle - są czytane z największą niechęcią. Studenci podkreślają ich stopień trudności lub (w ich przekonaniu) zwyczajnie nudny temat. Jednocześnie wielu studentów deklaruje, że źródłem informacji są właśnie polecane przez wykładowców książki i/lub czasopisma ( $88 \%$ badanych). Te deklaracje zdecydowanie osłabia nieprzeparta chęć łatwego dostępu do zasobów internetowych - do weryfikacji których nie każdy młody człowiek ma stosowne kompetencje poznawcze i chęć. Katarzyna Borawska-Kalbarczyk - po przeprowadzeniu badań kultury uczenia się studentów - określiła uczenie się współczesnego studenta jako leniwe (ang. lazy learning).

Podobne wyniki uzyskała Małgorzata Mikut, prowadząc badania wśród 162 studentów studiów magisterskich kierunku pedago-

${ }^{13}$ K. Borawska-Kalbarczyk, "Pokolenie C" w roli studentów - uczenie się w pułapce klikania? http://www.ktime.up.krakow.pl/symp2013/referaty_2013_10/borawska.pdf [dostęp: 12.04.2016]. 
gika na jednej ze szczecińskich uczelni wyższych (publicznej). Z wypowiedzi respondentów wynika, że spośród wielu źródeł (zarówno w wersji elektronicznej, jak papierowej), które "studiują", znaczną część stanowią kserokopie notatek kolegów i koleżanek (78,57\% wskazań wśród studentów niestacjonarnych i 65,09\% wskazań wśród studentów stacjonarnych), gotowe opracowania tematyczne zamieszczone $\mathrm{w}$ internecie $(45,28 \%$ wskazań wśród studentów stacjonarnych i 33,92\% wskazań wśród studentów niestacjonarnych) oraz Wikipedia (23,58\% wskazań wśród studentów stacjonarnych i $28,57 \%$ wskazań wśród studentów niestacjonarnych). Autorka konkluduje te wyniki nastepujaco:

istnieje duże prawdopodobieństwo, że to właśnie te źródła są głównym źródłem wiedzy znacznej części studentów. Analiza czasu, jaki przeznacza pewna część studentów na przygotowanie się do zajęć, w zestawieniu ze źródłami wiedzy studentów pozwala na wniosek, że zachodzi tu zjawisko pozorowania studiowania. Trudno wnioskować o jakimkolwiek przygotowaniu się do zajęć znaczącej grupy studentów (skoro wystarcza im do pół godziny czasu), chyba że rozumieją to jako mentalne nastawienie do zajęć, zdobycie/przygotowanie pomocy dydaktycznych (cokolwiek to znaczy) ${ }^{14}$.

Zjawisko pozorowania odnieść można także do faktu, że regularne przygotowanie do zajęć deklaruje 32,72\% studentów. Największy udział wśród przygotowujących się do zajęć mają studenci z najwyższymi wynikami (63,16\% wśród osób ze średnią 4,6-5,0). Jednak już wśród studentów ze średnią 3,5-4,0 tylko 10,42\% przygotowuje się do zajęć15.

Zwrócę uwagę, że 2,47\% badanych przez Mikut studentów przyznaje się, że w ostatnim roku nie przeczytało żadnej książki. Mniej niż połowa badanych studentów przyznaje się, że w ostatnim roku przeczytała do 10 książek i tyle samo deklaruje, że przeczytało

${ }_{14}$ M. Mikut, Zaangażowanie w studiowanie czy pozorowanie?, „Pedagogika Szkoły Wyższej” 2014, nr 1, s. 114.

15 Por. Ibidem, s. 111. 
do 20 książek i więcej16. Wyniki Mikut pozwalają optymistycznie powiedzieć, że studenci pedagogiki, w których formułę wpisuje się studiowanie wielu źródeł naukowych, średnio do jednego przedmiotu korzystali z jednej publikacji. Zauważę, że badania prowadzone były ze studentami ostatniego roku studiów, który kończy się pracą dyplomową, co wymaga studiowania wielu źródeł naukowych. Deklaracje badanych przez Mikut studentów dotyczące czytania dość dobrze wpisują się w raporty ogólnych badań czytelnictwa, z których wynika, że ani jednej książki w ciągu ostatniego roku nie przeczytało aż 33\% uczniów i studentów. Tekstu dłuższego niż trzy strony maszynopisu lub trzy ekrany monitora w ostatnim miesiącu nie przeczytało aż $27 \%$ uczniów i studentów ${ }^{17}$.

Można śmiało powiedzieć, że masowe odejście od książki i w ogóle od tekstu drukowanego, trafnie określane kryzysem czytania, dosięga coraz wyraźniej Uniwersytet. Dostrzega to chyba każdy, kto pracuje już jakiś czas w ośrodkach akademickich. Dodam, że podczas moich dyskusji ze studentami stwierdzają oni wprost, że czytać na studiach nie trzeba. Na pytanie, co czytają wskazują jedynie teksty wykorzystywane $\mathrm{w}$ trakcie pisania prac. Pojawiają się tylko nieliczne wskazania zajęć, na które trzeba coś czytać. Wyjaśnień można szukać w turystycznym charakterze współczesnych studiów i ukierunkowaniu kształtu studiów na zapotrzebowanie turysty ${ }^{18}$. Słowa przedstawiciela semiotyczno-dramaturgicznego ujęcia turystyki - amerykańskiego socjologa Deana MacCannella - w istocie dobrze odzwierciedlają sytuację współczesnego studenta i mechanizm jego wyobcowania wobec głębszych sensów, wobec czytania refleksyjnego czyli studiowania. „Potocznie obciąża się winą mentalność turysty, ale nie jest to słuszne. Fakt, że

16 Por. Ibidem, s. 115.

17 Por. D. Michalak, I. Koryś, J. Kopeć, Stan czytelnictwa w Polsce w 2015 roku: wstępne wyniki, Biblioteka Narodowa; 2016, s. 14, http://nck.pl/media/attachments/317 769/Stan \%20czytelnictwa \%20w\%20Polsce\%20w\%202015\%20r._BN_0416.pdf [dostęp: 2.09.2016].

18 S. Sadowska, "Trafiliśmy do nieznanego miasta, a ktoś poradził, żebyśmy zapuścili się w zarośla między dwiema nowymi kamieniczkami" - podróż po mieście naukowym pedagogiki specjalnej, „Człowiek - Niepełnosprawność - Społeczeństwo” 2014, nr 3. 
turysta nie potrafi zrozumieć tego, co widzi, jest pochodną stosunków w obrębie struktury, która nadaje jego związkowi z obiektem społecznym [...] charakter turystyczny"19. Lech Witkowski²0 zauważa, że prześciganie się w spełnianiu rynkowych oczekiwań potencjalnych odbiorców ofert edukacyjnych skazuje nas na faktyczne narastanie końca "kultury uczenia się”.

Znaczące jest istnienie dużego odsetku studentów nie rozumiejących polecanej lektury. Badania Mikut wskazują, że na nierozumienie czytanych treści wskazało 22,64\% studentów niestacjonarnych i 12,50\% studentów stacjonarnych ${ }^{21}$. Z badań BorawskiejKalbarczyk wynika, że do problemów ze zrozumieniem długiego tekstu w książce przyznaje się $14 \%$ studentów pierwszego roku ${ }^{22}$. Zofia Kłakówna, w odwołaniu do pracy ze studentami z obszaru nauk humanistycznych, wskazuje na podstawowe trudności studentów w czytaniu tekstów humanistycznych, łącząc je - dodam z przygotowaniem na niższych szczeblach edukacji. W jej opinii studenci poproszeni o streszczenie tekstu „nie biorą pod uwage faktu, że streszczany tekst prezentuje w części ujęcia historyczne i teorie sfalsyfikowane [...], nie zauważają, że znaczący może być czas powstania streszczanego tekstu, ani to, z jakiej perspektywy kulturowej pisze nieżyjący już od paru lat autor, tekst opublikowany traktują jak niepodważalną prawdę, nie zaś jako wyraz jednego z możliwych stanowisk"23. Kluczowa kwestia według autorki dotyczy trudności odczytań i oceny stanowisk/teorii z różnych okresów rozwoju nauki. Studenci pedagogiki specjalnej, z którymi pracuję, przejawiają takie same trudności. Wyraźnym tego świadectwem jest ich samodzielne poszukiwanie literatury - zupełnie pomijają kwestię lat wydania źródeł, nie wiedzą, gdzie i jak szukać. Dla nas -

19 Za: K. Podemski, Socjologia podróży, Wydawnictwo Naukowe UAM, Poznań 2005, s. 63.

${ }^{20}$ L. Witkowski, op. cit., s. 289.

21 Por. M. Mikut, op. cit., s. 111.

22 K. Borawska-Kalbarczyk, op. cit.

23 Z. Kłakówna, Jakoś i jakość. Subiektywna kronika wypadków przy reformie szkoły (1989-2013), Wydawnictwo UNIVERSITAS, Kraków 2014, s. 244. 
osób zajmujących się naukowo pedagogiką specjalną - oczywiste jest, że uwikłanie historyczne, społeczne i kulturowe zjawisk wychowawczych/rehabilitacyjnych sprawia, że w tej nauce, chyba wyraźniej niż w jakiejkolwiek innej, rozpoznania prowadzi do mniej lub bardziej zadowalających ustaleń, które często po pewnym czasie okazują się niewystarczające. Rozumiemy, że zmienna czasu ujawniająca się w filozoficzno-kulturowym kontekście uprawiania nauki (co przyrównać można do mentalności danej epoki) daje o sobie znać zarówno w metodologicznym wzorcu jej uprawiania, jak i w interpretowaniu przez badaczy kwestii dotyczących życia człowieka z niepełnosprawnością, w tym i jego wychowania. Rozumiemy też, że cechą szczególną tej dyscypliny nauki jest zmienność słownika i „pojęciowy gwar” 24 . Studentom obca jest hierarchizacja zdobytej wiedzy, mają zaburzone przeczucie całości wiedzy, punkty odniesienia - a wówczas podroż po świecie nauki staje się niemożliwa Odwołam się tu jeszcze raz do trafnych słów Jacka Dehnela - eseisty, prozaika:

Żeby wiedzieć, gdzie i jak szukać, jaka jest hierarchia źródeł, trzeba mieć w głowie mapę dziedzin wiedzy, obraz kultury, w którym książki, dzieła naukowe, wydarzenia historyczne, prądy intelektualne, postaci łączą się w jedną sieć, po której użytkownik kultury swobodnie się przemieszcza ${ }^{25}$.

Zwrócę uwagę, że interesującą propozycję, by pomóc czytelnikowi w odbiorze prac z różnych okresów rozwoju pedagogiki specjalnej, podjęli autorzy książki Rozumieć chaos. Rzecz o terminach $i$ znaczeniach nadawanych w pedagogice specjalnej26. Rzecz w tym jednak, żeby studenci chcieli się w nią zagłębić.

24 Por. S. Sadowska, W poszukiwaniu potencjału uprawiania pedagogiki specjalnejperspektywa naukoznawcza i metodologiczna, [w:] Pedagogika specjalna - tak wiele pozostaje tajemnica, red. S. Przybyliński, Wydawnictwo UWM, Olsztyn 2010, s. 221-232.

25 J. Dehnel, op. cit., s. 264-265.

26 S. Olszewski, K. Parys, Rozumieć chaos. Rzecz o terminach i znaczeniach im nadawanych w pedagogice specjalnej, Wydawnictwo Naukowe Uniwersytetu Pedagogicznego, Kraków 2016. 
Kwestię wyjaśnień opisanych zachowań i trudności studentów można odnieść do szerokich zmian, jakie wiążą się z faktem, że studenci, których teraz uczymy, należą do pokolenia C (termin ten odnoszony jest do osób urodzonych po 1990 r.). Pokolenie C opisywane jest za pomocą trzech cech charakterystycznych: computerized (skomputeryzowani), connected (podłączeni), always clicking (ciągle klikający). Są to osoby, które mają wręcz nieograniczony dostęp do informacji, co jednak nie pociąga za sobą posiadania i rozumienia wiedzy ${ }^{27}$. Podkreśla się, że środowisko cyfrowe zachęca ludzi do zapoznawania się z większą liczbą różnych tematów, ale powierzchowniej. Wskazuje się, że współcześni użytkownicy sieci korzystają z niej raczej po to, by unikać czytania w konwencjonalnym znaczeniu tego słowa. Charakterystyczną cechą tego czytania jest to, że jest to czynność hipertekstualna. Użytkownicy dokumentów elektronicznych dokonują stałych przejść lub zmian pomiędzy funkcją czytelnika i funkcją nawigatora. Odchodzą od tekstu, traktując dokument elektroniczny jako nośnik - medium (wykorzystując jego możliwości wyszukiwawcze - przeglądanie i nawigację). Czytają teksty, przełączając się cały czas pomiędzy kilkoma równolegle otwartymi źródłami. Czytają kilka rzeczy naraz. Jeśli nie rozumieją jakiegoś sformułowania, to otwierają drugie okno i szukają wyjaśnień28. Badacze sygnalizują, że u młodych ludzi podatnych na wpływy i spędzających każdy wolny czas w internecie, wykształcają się tzw. hipertekstowe umysły. Ich sposób myślenia przebiega wielowątkowo, nie są zdolni do głębszej refleksji, przyjęcia szerszego punktu widzenia czy wyciągnięcia wniosków. Ich umysł jest nastawiony na przyjmowanie wiadomości w taki sposób, w jaki dostarcza ich internet, czyli w postaci szybko płynącego strumienia danych. Chodzi o przystosowanie do wielozadaniowości, szybkiego przesiewania wielu informacji i decydowania, które $z$ nich są ważne. Doniesienia badawcze częstokroć są sprzeczne. $Z$ jednej strony wskazuje się, że środowisko internetu powoduje czytanie powierz-

${ }^{27}$ K. Borawska-Kalbarczyk, op. cit.

${ }_{28}$ M. Nahodko, op. cit., s. 139. 
chowne, pośpieszne; hiperlinki przeszkadzają ludziom w czytaniu i w głębokiej refleksji, co nie sprzyja budowaniu własnych struktur wiedzy, koncentracji i rozumieniu tekstu, z drugiej, że interaktywne informacje przeczytane $\mathrm{w}$ internecie są lepiej zapamiętywane, a czytanie online jest trudniejsze, wymaga nowych umiejętności ${ }^{29}$.

Wydawać się może, że wykorzystywanie internetu w celach naukowych jest dla młodych ludzi naturalne, jednak badania i codzienne obserwacje studentów wskazują na to, że bardzo wielu studentów ogranicza się, używając żargonowego pojęcia, jedynie do „zgooglowania” tematu. Studenci nie zdają sobie sprawy, że w ten sposób nie są w stanie dotrzeć do znacznej części materiałów. Nie znają mechanizmów działania wyszukiwarek internetowych oraz baz bibliotek wirtualnych. Moje rozpoznanie wskazuje, że nawet trudno ich zaliczyć do grupy nie-użytkowników bibliotek cyfrowych (nie-użytkownik do osoba odwiedzająca bibliotekę cyfrową, ale niekorzystająca z żadnej usługi). Niepokojące są zwłaszcza umiejętności studentów ostatnich lat lub tuż po dyplomie, kiedy przychodzą do biblioteki w związku z pracą magisterską czy doktoratem. $Z$ reguły brak im przygotowania do systematycznej pracy naukowej czy umiejętności efektywnego korzystania ze środowiska cyfrowego. Dodam, że Jolanta Mazurek podaje, iż prawie dwie trzecie korzystających z bibliotek cyfrowych korzysta z nich mniej niż 30 sekund, co wyklucza czytanie czegokolwiek, a nawet zapoznanie się z ofertą ${ }^{30}$.

Na omawiane kwestie można spojrzeć w perspektywie przygotowania studentów do racjonalnego postępowania z lekturą naukową, zapoznania ze sposobami studiowania dzieła naukowego. Chodzi tu zarówno o etap intelektualnego i emocjonalnego przygotowania do studiów na wcześniejszych etapach edukacji oraz o rozwiązania edukacyjne $\mathrm{w}$ trakcie studiów wyposażające młodych ludzi w umiejętności tworzenia swojego warsztatu pracy,

${ }^{29}$ N. Bednarska, Wikipedia na uczelni i w szkole - przyszli nauczyciele o Wikipedii, „Ruch Pedagogiczny” 2015, nr 1, s. 141.

30 Za: M. Nahodko, op. cit., s. 145. 
a także wzbudzające ciekawość poznawczą. Problematyzując w jednym ze swoich wcześniejszych tekstów kwestię podróży po mieście naukowym pedagogiki specjalnej, uwagi dotyczące studenckiej prepodróży wyraziłam następująco:

Myśląc o wcześniejszej edukacji studentów, z którymi pracuję, często przychodzi mi na myśl, że okradła ona młodych ludzi z narzędzi pozwalających wyruszyć w podróż po świecie nauki. Wyobrażam sobie pozostając $w$ konwencji podróży - że bagażnik samochodu nauczycieli, którzy wybierali się $\mathrm{z}$ nimi $\mathrm{w}$ drogę, nie dał się domknąć, a przy jego pakowaniu zabrakło myślenia o wadze edukacji dla nauki szukania ${ }^{31}$.

Dostrzegając konieczność poszukiwania nowego modelu pracy dydaktycznej i odpowiednich sposobów kierowania procesem studiowania, wskazywałam (w odwołaniu do refleksji teoriopoznawczej), że wzorem myślenia w działaniach akademickich może być Bachelardowska pedagogika. Chodzi o położenie dużego nacisku na stale odnawiany wysiłek poznawania idącego pod prąd utrwalonych oczywistości. Przesłanką dla tego wzorca dydaktycznego były granice naszego myślenia wyznaczone społecznymi uzgodnieniami dotyczącymi osób z niepełnosprawnością i ich miejsca w codziennym życiu oraz złożoność i wieloparadygmatyczność miasta naukowego pedagogiki specjalnej. Dzisiaj dodam, że znaczący jest dobór tekstów do czytania. Prowadzący zajęcia, którzy mają monopol na ustanawianie przestrzeni tekstów do czytania w ramach prowadzonych zajęć, proponują zbyt często takie, które nie wymagają wysiłku myślowego, które nie umożliwiają podejmowania krytyki naukowej. W perspektywie nowej rzeczywistości cyfrowej możemy też mówić o zmonopolizowani przestrzeni czytania przez teksty, których dostarczy studentowi wyszukiwarka Google. Ponownie zauważę, że studentów należy uczyć efektywnego korzystania ze środowiska cyfrowego. W tym kontekście przywołam na koniec uwagę, że prawdziwe studiowanie zaczyna się dopiero wtedy, kiedy Google nie wie, o co chodzi.

31 S. Sadowska, op. cit., s. 23. 


\section{Zakończenie}

Czytać w pojęciu naukowym to znaczy przede wszystkim pojąć sens. Z punktu widzenia nauczyciela, $\mathrm{w}$ tym także akademickiego, nie jest istotne to, $\mathrm{z}$ jakiego nośnika korzystają studenci, czytając. Priorytetem jest to, aby czytali, analizowali teksty, wyciągali wnioski, krytycznie oceniali zawarte $w$ nich informacje, twórczo rozwijali przedstawione $\mathrm{w}$ nich myśli. Głosy przedstawicieli środowiska naukowego, niezależnie od reprezentowanej dyscypliny, są $\mathrm{w}$ tym zakresie podobne, tak jak w zakresie myślenia o zadaniach uniwersytetu i jego słabościach.

Uniwersytet to jest otwarcie na świat. To nie może być instytucja, która wypuszcza specjalistów od bardzo wąskich dyscyplin, bo nie to jest jej fundamentem. [...] Uniwersytet daje wędkę, pokazuje, gdzie trzeba szukać wiedzy, jak z niej korzystać i jak samemu się dokształcać32.

Uniwersytet powinien być źródłem edukacji ogólnej, a nie początkiem kariery zawodowej. Uniwersytet powinien otwierać klapki w głowie, uczyć krytycznego myślenia i wyposażać młodego człowieka w pożyteczne umiejętności (języki i inne, w zależności od kierunku - np. analizę danych). Student powinien czytać i pisać. Dużo czytać i pisać. [...] Marzy mi się uniwersytet, na którym studenci naprawdę studiują, a nie tylko uczą się przez kilka dni sesji, by zdać egzamin. Uniwersytet powinien różnić się od wyższej szkoły zawodowej33.

Jako reprezentantka środowiska naukowego pedagogów specjalnych w pełni uznaję słowa wypowiedziane przez profesor biologii i filologii romańskiej. Dostrzegam, że wiele negatywnych zjawisk na Uniwersytecie pojawiło się w następstwie realizacji zaleceń Procesu Bolońskiego w rodzimym systemie edukacji. Dodam, że modyfikacje modelu studiów nauczycielsko-pedagogicznych, jak też ich programów, standardów kształcenia i oczekiwanych po ich

32 M. Świątkowska, W poszukiwaniu moich sensów, [w:] Uniwersytet Jagielloński: Z naukowcami o nauce, op. cit., s. 78, www.nauka.uj.edu.pl [dostep: 29.08.2016].

${ }^{33}$ G. Jasieńska, Twórcza mobilność, [w:] Uniwersytet Jagielloński: Z naukowcami o nauce, op. cit., s. 122, www.nauka.uj.edu.pl [dostęp: 29.08.2016]. 
ukończeniu efektów, są kontrowersyjne ${ }^{34}$. To, co daje się zaobserwować w przestrzeni kształcenia pedagogów i nauczycieli, w tym pedagogów specjalnych, przypomina model szkolenia.

Nazwa „uniwersytet” zobowiązuje. W czasach, gdy sama studiowałam, prowadzący zajęcia wpajali nam, że warunkiem koniecznym uczenia się jest takie rozumienie, które prowadzi do jakościowych zmian w naszej wiedzy i postawach. Wśród studentów panowała wówczas naukowa atmosfera. Nieodłącznym elementem procesu studiowania było czytanie. Moim studentom, w przekonaniu, że czytanie jest znaczące dla ich myślenia i postaw, polecam (o ile będą czytelnikiem tego tekstu) naukę ze szkoły Isochara w Smyrnie, z lektury Ksiag Jakubowych.

Wziąłem sobie do serca to, czego nauczał nas Isochar. [...] Jest czytelnik gąbka, czytelnik lejek, czytelnik cedzidło i czytelnik sito. Gąbka wchłania w siebie wszystko, jak leci; jasne jest, że potem dużo z tego pamięta, lecz nie umie wydobyć najważniejszego. Lejek - przyjmuje jednym końcem, drugim zaś wszystko, co przeczytane, z niego wylatuje. Cedzak przepuszcza wino, a zatrzymuje winny osad; ten w ogóle nie powinien czytać i lepiej, żeby zajął się rzemiosłem. Sito zaś oddziela plewy, żeby otrzymać najlepsze ziarno. «Chciałbym, żebyście byli jak sito i nie zatrzymywali tego, co niedobre i nudne» - mawiał do nas Isochar ${ }^{35}$.

\section{Bibliografia}

Bednarska N., Wikipedia na uczelni i w szkole - przyszli nauczyciele o Wikipedii, „Ruch Pedagogiczny" 2015, nr 1.

Borawska-Kalbarczyk K., „Pokolenie C” w roli studentów - uczenie się w putapce klikania? http://www.ktime.up.krakow.pl/symp2013/referaty_2013_10/boraw ska.pdf [dostęp: 12.04.2016].

34 Por. Z. Janiszewska-Nieścioruk, S. Sadowska, Trening protiv obrazovaniâ? Raznoglasiâ, svâzannye s rasprostraneniem pro-Bolonskogo obrazovaniâ pedagogov $i$ učitelej $v$ Pol'še, [w:] Viŝa osvita Ukraïni u kontekstì integraciï do Evvropejs'kogo osvitn'ogo prostoru $=$ Higher education of Ukraine in the context of integration to European educational space, red. Í.P. Manoha, Kijów 2015.

35 O. Tokarczuk, Księgi Jakubowe, Wydawnictwo Literackie, Kraków 2014, s. 749. 
Dehnel J., Młodszy księgowy. O książkach, czytaniu i pisaniu, Wydawnictwo: W.A.B., Warszawa 2013.

Janiszewska-Nieścioruk Z., Sadowska S., Trening protiv obrazovaniâ? Raznoglasiâ, svâzannye s rasprostraneniem pro-Bolonskogo obrazovaniâ pedagogov i učitelej $v$ Pol'še, [w:] Viŝa osvita Ukraïni u konteksti integraciï do Êvropejs'kogo osvitn'ogo prostoru = Higher education of Ukraine in the context of integration to European educational space, red. Í.P. Manoha, Kijów 2015.

Jasieńska G., Twórcza mobilność, [w:] Uniwersytet Jagielloński: Z naukowcami o nauce, red. P. Żabicki, Kraków 2016, www.nauka.uj.edu.pl [dostep: 29.08.2016].

Kłakówna Z., Jakoś i jakość. Subiektywna kronika wypadków przy reformie szkoły (1989-2013), Wyd. UNIVERSITAS, Kraków 2014.

Kołodziejska E., Przy herbacie. Rozmowy z Edwardem Hajdukiem, Wydawnictwo Uniwersytetu Zielonogórskiego, Zielona Góra 2012.

Michalak D., Koryś I., Kopeć J., Stan czytelnictwa w Polsce w 2015 roku: wstępne wyniki, Biblioteka Narodowa; http://nck.pl/media/attachments/317769/Stan\%20czy telnictwa\%20w\%20Polsce\%20w\%202015\%20r._BN_0416.pdf [dostep: 2.09.2016].

Mikut M., Zaangażowanie w studiowanie czy pozorowanie?, „Pedagogika Szkoły Wyższej" 2014, nr 1.

Nahodko M., Wptyw nowych technologii na czytanie naukowe, [w:] Czytelnictwo w dobie informacji cyfrowej. Rozwój, bariery, technologie, red. M. Wojciechowska, Wydawnictwo SBP, Warszawa 2015.

Olszewski S., Parys K., Rozumieć chaos. Rzecz o terminach i znaczeniach im nadawanych w pedagogice specjalnej, Wydawnictwo Naukowe Uniwersytetu Pedagogicznego, Kraków 2016.

Podemski K., Socjologia podróży, Wydawnictwo Naukowe UAM, Poznań 2005.

Sadowska S., W poszukiwaniu potencjatu uprawiania pedagogiki specjalnej - perspektywa naukoznawcza i metodologiczna, [w:] S. Przybyliński (red.), Pedagogika specjalna - tak wiele pozostaje tajemnicą, Wyd. UWM, Olsztyn 2010.

Sadowska S., "Trafiliśmy do nieznanego miasta, a ktoś poradzit, żebyśmy zapuścili się w zarośla miedzy dwiema nowymi kamieniczkami" - podróż po mieście naukowym pedagogiki specjalnej, „Człowiek - Niepełnosprawność - Społeczeństwo” 2014, nr 3.

Szwecja czyta. Polska czyta, red. Tybylewicz K., Diduszko-Zyglewska A., Wydawnictwo Krytyki Politycznej, Warszawa 2015.

Świątkowska M., W poszukiwaniu moich sensów, [w:] Uniwersytet Jagielloński: Z naukowcami o nauce, red. P. Żabicki, Kraków 2016, www.nauka.uj.edu.pl [dostep: 29.08.2016].

Tokarczuk O., Księgi Jakubowe, Wyd. Literackie, Kraków 2014.

Uniwersytet Jagielloński: Z naukowcami o nauce, red. Żabicki P., Kraków 2016, www.nauka.uj.edu.pl [dostep: 29.08.2016].

Witkowski L., Wstęp do fenomenologii czytania (uwagi nie tylko seminaryjne), [w:] Między pedagogika, filozofia i kulturą: studia, eseje, szkice. T. 3., red. L. Witkowski, Instytut Badań Edukacyjnych, Warszawa 2007.

Witkowski L., Wyzwania autorytetu, Oficyna Wydawnicza „Impuls”, Kraków 2009. 